\title{
Information citizenship for the generations
}

\author{
Melanie Sutton \\ Information Officer \\ The IQ Business Group \\ msutton@iqgroup.net
}

\section{Introduction}

Generations have existed since recorded humanity and the rapid advances in technology and media combined with societal changes have given each generation in the last century its own unique set of experiences and values. Although by no means a scientific formula or rigorously researched model, generational theory provides a form of generational identity and a measuring stick into a period of time that produces people who tend to think and act in a similar manner at a certain time (Codrington and Grant-Marshall 2004).

Generational theory is of particular significance as we seek to develop. Information citizenship among all generations, especially in the workplace. Understanding our generational profiles, our learning styles and our information behaviour will help us to develop inter-generational information citizenship behaviour, where all members can fully participate and reap the benefits of the information economy.

\section{Generations and generational theory}

A generation is defined as a whole body of persons born about the same time, while a generational gap refers to the differences of opinion between those of different generations. A generational cycle is a four part process of history, spanning roughly 80 years, defined by successive 20 year cohorts of idealistic, reactive, civic and adaptive characteristics (Strauss and Howe, quoted in Codrington and Grant-Marshall 2004)

While not everyone who experiences an event thinks and acts in the same way, generational cycles help us to identify moments in the history of the twentieth century in different countries and cultures where similar defining forces were brought to bear on families, communities and societies. We are able to generalize about the influence this may have had on the generation of young people who were growing up at the time.

Generational theories allow us to examine both peer influences and the interactions between members of different generations in the school, workplace or community. As citizens of the information economy, it is important that we recognize our generational differences so that we can a) be aware of how we behave; and b) be aware of how other citizens behave. If we have this basic understanding, our mechanisms of sharing information, becoming life-long learners and behaving as information literate citizens improve.

Margaret Mead was the first sociologist to identify generational theory, whereafter an American Morris Massey popularized generational theory in the 1970s with a lecture tour on what is known today as the 'baby boom' generation. It was William Strauss and Neil Howe, 
authors of the book Generations, the history of America's future, 1584 to 2069, who popularized generational theory. Generations recognizes that since 1584, American society has experienced four cycles of generations each with four phases, and now they are at the 'turning' of the fourth cycle.

There is much debate around the correct dating for the different generations. The author refers to the South African guide as defined by Codrington and Grant-Marshall (2004).

\section{Defining the generations}

\subsection{GIs born between 1900 and 1929}

GIs are named after the general issue or government issue clothes that became synonymous with the soldiers of both world wars and are indicative of their attitude to community and regularity. It was their ability to work as a team, to fight together as a unit and obey hierarchical chains of command which enabled them to overcome the combined events of both World War I and the Great Depression. A key information-centric invention during this time was television.

For GIs, learning was largely considered to be the accumulating and memorizing of facts and they were therefore more interested in formal classroom training. They enjoy learning and some want to learn how to operate computers, are keen to learn how to email and SMS. These generations should not be humiliated by their lack of twenty-first century technical knowledge (Codrington and Grant-Marshall 2004).

\subsection{Silents born between 1930 and 1949}

Born during World War II and the Great Depression, they learnt not to trust others for their security. To this day, they are self-reliant, something they regard as a virtue. They are strong believers that it is both honourable and normal to work hard and that anything can be achieved by sheer hard work. Silents were caught between the thirty-something returning war heroes and the coddled, post-war baby boomers. Key information centric inventions include the photocopier, computer (ENIAC), Bell telephone, instant photography and bar codes. Silents enjoy conformity, consistency, logic and discipline. Silents enjoy pre-reading and prefer receiving training on a one-on-one basis, especially when it is related to technology. They appreciate the classical, straightforward presentation of information, they are motivated by training that is linked to the overall good of the company. They want handouts, not electronic notes or a list of Web sites (Codrington and Grant-Marshall 2004).

\subsection{Boomers born between 1950 and 1969}

Boomers were born during a time when the dreariness of the war-rationed years was fading and life was characterized by materialism and freedom. They produced one of the strongest, longest and most sustained growth spurts in history. Boomers are happy with the system of authority as long as they are in authority themselves. They are principled, moralistic and domineering and transformed themselves into a solid materialistic middle class. Key information centric inventions include colour television and remote control, microchips, credit cards, the computer mouse, automated teller machines (ATM) and video cassette recorders. Boomers are strong supporters of deductive analysis and brainstorming. They are well educated and enjoy opportunities for interaction, networking and teamwork. Boomers intellectualize and are often not aware that while they may have the knowledge, it does not mean they have the skills. Information must be readily accessible, for example, a hyperlinked Web site with an overview of information in a friendly, easy-to-scan format. Interestingly, most international electronic news, magazines are structured in this manner (Codrington and 


\subsection{Xers born between 1970 and 1989}

Xers were born into an economy that was flattening and a society where the divorce rate was rapidly increasing. Xers are characterized by long friendships that can elude other generations, a better life balance, a non-traditional approach to worklife and an ability to forge new employment opportunities that are often overlooked by established businesses. Key information centric inventions include smart cards, personal computers, compact discs, walkmans, video games, mobile phones and laptop computers. To older generations, Xers often seem impatient for answers, always demanding information, asking questions and pursuing multiple lines of enquiry simultaneously. This is often taken as lack of attention span, whereas it is in fact a style of interacting with the information which comes naturally to these children of the information revolution. Today's young people think in sound bites, big pictures and concepts, with an incredible capacity for information gathering. They want to be able to communicate 24 hours a day, seven days a week, anywhere in the world. They know that learning is a lifelong career in itself so they want training that is related to personal skills development and increased personal marketability (Codrington and Grant-Marshall 2004).

\subsection{Millennials born between 1990 and 2005}

Born into a world immersed in a world of computers and other information technologies, millennials demand reasons and rationale which confuses and irritates older generations, especially GIs and silents who think that they did as they were told and so should they. Millennials will demand worklife balance. They are wise and wiser than any other generation at the same age. They are reading and questioning more. They have an underlying desire to do the right thing, to know the truth of a situation, to have a job that means more than a pay cheque and to live a life that matters. Key information centric inventions include personal digital assistants, digital video discs; digital cameras and memory sticks, HTML Web pages, broadband Internet and quadraphonic cell phones. Millennials will look for more attention and structure from their bosses and respond well to mentorship, personal authority and they respect qualifications and expertise. They prefer discovering information, and learn by solving problems and using multiple means of communication and whole-brain intelligence. Millennials need to be taught how to learn (in their own individual style) and how to love the process of learning, because they will truly be engaging in lifelong learning (Codrington and Grant-Marshall 2004; Walter 2005).

\subsection{Cuspers}

These are people who fall in between generations, into the overlap between two generations and display characteristics of both the preceding generation and their own generation and have adopted some of the characteristics of the following generation. Cuspers make the best of two worlds and may not feel the discomfort that people who are really typical of one generation experience with another. Cuspers are extremely valuable in multi-generational work environments as they generally behave as generational mediators.

\section{Intergenerational information citizenship}

Generational change has always been a primary dynamic in the life of societies but the changes that lie ahead flowing from the combination of more extensive satellite television and ever greater Internet literacy may be as profound as any that have previously marked the modern era (Rosenau 2002).

There is at present a generational divide between young people and older people with respect 
to their familiarity and comfort with digital technologies and coping in an information centric society. It is vital that the older generations are not systematically left behind, and development of their technological fluency (IT literacy) is vital (Australian Government, Department of Education, Science and Technology 2005).

Today's older generations have been largely perplexed and intimidated by the Internet and its potential uses, so much so that many of their members assume that their learning curve does not allow for keeping up with and using the access to the knowledge and communications afforded by the Internet. Partly the perplexity stems from an inability to grasp the underlying processes on which the Internet and its numerous dimensions are founded (Rosenau 2002).

An valuable approach to addressing this problem and ensuring the transmission of culture across generations and building stronger communities and capable information citizens is through intergenerational programmes and policies. These intergenerational programmes link youth and adults are an increasingly popular means of improving the lives of both generations as they increase cooperation, interaction or exchange between any two generations. They involve the sharing of skills, knowledge and experience between old and young. An example is young people assisting older adults to learn to use computer technology (Lawrence-Jackson 2003). Intergenerational programmes empower individuals and advance the skill revolution. In South Africa, the average age of Web users is 35, but with the biggest age group being those between 20 and 30 (Rosenau 2002).

\section{Conclusion}

Generational theory is a tool that we can use to understand our own behaviour as well as behaviour of others in the information economy. It is a filter that we can use to improve our information citizenship in terms of our approach to information behaviour and lifelong learning. It is a mechanism to consciously create intergenerational knowledge sharing and a guide to making the information economy more appealing and accessible to society.

\section{References}

Australian Government, Department of Education, Science and Training. 2005. Linking thinking - self directed learning in the digital age. [Online]. Available WWW:

http://www.dest.gov.au/sectors/training_skills/

publications_resources/profiles/linking_thinking.htm.

Codrington, G. and Grant-Marshall, S. 2004. Mind the gap. South Africa: Penguin Books.

Lawrence-Jackson, A.R. 2004. Bridging the generational divide of an ageing population. [Online]. Available WWW: http://www.cmif.org/Conf2004/Docs/Handout.pdf.

Rosneau, J.N. 2002. Generational change and Internet literacy. [Online].

Walter, S. 2005. Born digital: looking at information literacy instruction through a generational lens. [Online]. Available WWW: https://kuscholarworks.ku.edu/ dspace/bitstream/1808/246/1/WLA_05.ppt.

\footnotetext{
About the author

Melanie Sutton (BA, Postgraduate Diploma in Information Management) is a Senior Principal Consultant in the Enterprise Content Management Discipline and a member of Intellectual Property Forum at The IQ Business Group, South Africa.
} 
Articles published in SAJIM are the opinions of the authors and do not necessarily reflect the opinion of the Editor, Board, Publisher, Webmaster or the Rand Afrikaans University. The user hereby waives any claim he/she/they may have or acquire against the publisher, its suppliers, licensees and sub licensees and indemnifies all said persons from any claims, lawsuits, proceedings, costs, special, incidental, consequential or indirect damages, including damages for loss of profits, loss of business or downtime arising out of or relating to the user's use of the Website.

ISSN 1560-683X

Published by InterWord Communications for Department of Information and Knowledge Management, University of Johannesburg 